\title{
Experimental Investigation on the Effect of Specimen Size in Determining Fracture Parameters of Concrete
}

\author{
Siregar, A.P.N. ${ }^{*}$, Rafiq, M.I. ${ }^{2}$, and Mulheron, M. ${ }^{3}$
}

\begin{abstract}
This paper presents the experimental results in investigating the effect of specimen size (ratio of beam width to aggregate size) on the value of stress intensity factor $\left(K_{I C}\right)$ and fracture energy $\left(G_{F}\right)$ using three-point bend (TPB). A test method recommended by RLEM was chosen to measure the $K_{I C}$ and the $G_{F}$ as fracture parameters. Three different specimen sizes of concrete beam with water/binder ratio of 0.2 and 0.30 were engaged in the experiments. Both qualitative and quantitative analyses based on the normalized stress against deflection curve, and the $K_{I C}$ and the $G_{F}$ were employed. Statistical analysis was carried out based on coefficient of variation of the measured value of fracture parameters in order to investigate the variability of corresponding results. It was found that specimen size have a relatively insensitive influence on the value of $K_{I C}$, however, have a significant effect on the value of $G_{F}$.
\end{abstract}

Keywords: Concrete; stress intensity factor; fracture energy; specimen size.

\section{Introduction}

Concrete is a common composite material that has been widely used in the construction industry to build structures such as high rise buildings, bridges, and towers. The mechanical and fracture behavior of structures are dependent on the type of material used. Fracture characteristic of concrete is determined by stress intensity factor, $K_{I C}[1,2]$ and total dissipated fracture energy, $G_{F}[3,4]$. As the $K_{I C}$ and the $G_{F}$ represent the fracture characteristic of a material, these are then considered to be fracture parameters. These parameters have been widely used to determine the fracture behavior of materials [1-8]. Volume of concrete in the RC structures is mostly occupied by aggregates, up to $70 \%$ of total volume of concrete [9]. As a consequence, the properties of aggregate induce significantly in the fracture process of the structure which can be examined by its fracture parameters, i.e. stress intensity factor, $K_{I C}[10]$ and total fracture energy, $G_{F}$ [11]. Properties of aggregate such as size, shape, texture, and amount of aggregate have been widely investigated in terms of its effect on the fracture energy of hardened concrete [12-17].

\footnotetext{
1. Civil Engineering Department, Tadulako University, Л. Soekarno Hatta Km. 9, Palu, Sulawesi Tengah, INDONESIA

2 School of Engineering and Technology, University of Brighton, UNITED KINGDOM

${ }^{3}$ Department of Civil and Environmental Engineering, University of Surrey, Guildford, Surrey, UNITED KINGDOM

* Corresponding author; e-mail: atur_pns@yahoo.com
}

Note: Discussion is expected before November, $1^{\text {st }} 2016$, and will be published in the "Civil Engineering Dimension" volume 19, number 1, March 2017.

Received 09 April 2016; revised 06 June 2016; accepted 13 June 2016
Aggregate size as one of the properties of aggregate is then considered to predict the $G_{F}$ value of concrete as proposed by CEB-FIP Model Code 1990 [18], Bazant's formula [19], and CEB-FIP Model Code 2010 [20]. It shows that aggregate size is an important variable influencing the fracture characteristic. Thus, the size of aggregate is engaged as a parameter for proposing an adequate size of specimen to determine the $G_{F}$ value of concrete. The fracture characteristic of material is dependent on the fracture mechanisms such as initiation of crack, propagation of crack growth, aggregate interlocks, and arrest of crack. These mechanisms will proceed appropriately when having an adequate space in the concrete. A beam having width of $100 \mathrm{~mm}$ and concrete mix using maximum size of $16 \mathrm{~mm}$ is recommended to be used in testing according to RILEM TC50-FCM recommendation [21]. In the construction industry, concrete is not only manufactured by a definite size of aggregate, but it is dependent on availability of aggregate. Bazant and Oh [22] based on their experimental results, suggested to use a minimum beam width of three times maximum aggregate size $\left(d_{\mathrm{a}}\right)$ used in testing, as the width of fracture process zone of the concrete is three times maximum size of aggregate. As the specimen size has been proposed to be characterized by the aggregate size, therefore, the aim of this paper is to investigate the effect of specimen sizes in the fracture parameters of concrete.

\section{Materials}

The coarse aggregate used in this study was Thames Valley river gravel with the maximum and minimum particle size of $16 \mathrm{~mm}$ and $5 \mathrm{~mm}$ respectively. The sand fraction comprised a weathered river 
gravel of size ranging from $4 \mathrm{~mm}$ down to $0.30 \mathrm{~mm}$. The Portland cement binder employed was a CEM Type I material, with a specific surface area of 338 $\mathrm{m}^{2} / \mathrm{kg}$, incorporating Pulverized Fuel Ash (PFA) complying with BS EN450-1 [23]. A slurry-based silica fume complying with BS EN 12363-1 [24] was employed in some of the mixes for producing high strength concrete. A poly-carboxylate polymer based superplasticizer was employed to allow adequate workability and ensure full compaction of the concrete by keeping the slump value for all the mixes as $120 \pm 20 \mathrm{~mm}$. The proportions of each material used for the concrete mixes produced are shown in Table 1.

\section{Specimen Preparation}

The compressive strength of the hardened concrete was determined by crushing at least nine cubes (100 x 100 x $100 \mathrm{~mm}$ ) following BS EN 12390-3 (2001) [25]. The fracture parameters were calculated using beam specimens tested as shown in Table 2 and Figure 1. Three-point bend (TPB) test method proposed by RILEM TC 50-FCM Recommendation [21] is used. All specimens were de-molded approximately 24 hours after casting and water cured at 22 $\pm 2{ }^{\circ} \mathrm{C}$ for 30 days prior to testing.

Figure 1 shows the geometry of the beam specimen and the associated test arrangement. The width $(t)$, the depth $(D)$ and the total length $(L)$ of the beam are presented in Table 2 with a support span (S). A notch depth $\left(\mathrm{a}_{\mathrm{o}}\right)$ was employed in all of the specimens and was created using a water-cooled diamond rotary cutter with a blade width of $2.5 \mathrm{~mm}$.

Table1. Mix Proportion

\begin{tabular}{|c|c|c|c|c|c|c|c|}
\hline \multirow[b]{2}{*}{ Mix } & \multirow[b]{2}{*}{$\mathrm{w} / \mathrm{b}^{*}$} & \multirow{2}{*}{$\begin{array}{c}\text { Max. } \\
\text { aggregate } \\
\text { size- } d_{\mathrm{a}} \\
(\mathrm{mm})\end{array}$} & \multicolumn{5}{|c|}{ Unit weight $\left(\mathrm{kg} / \mathrm{m}^{3}\right)$} \\
\hline & & & $\begin{array}{l}\text { Aggre- } \\
\text { gate }\end{array}$ & cement PFA & $\begin{array}{l}\text { Silica } \\
\text { fume }\end{array}$ & water & $\begin{array}{c}\text { Super- } \\
\text { plasticizer }\end{array}$ \\
\hline$\overline{\mathrm{A} 1}$ & 0.30 & 16 & 868.85 & 438.50 & - & 131.6 & 0.07 \\
\hline $\mathrm{A} 2$ & 0.30 & 10 & 868.85 & 438.50 & - & 131.6 & 0.10 \\
\hline A3 & 0.20 & 16 & 868.85 & 367.4041 .47 & 29.63 & 87.7 & 1.09 \\
\hline
\end{tabular}

*Total water/binder ratio

Table 2. Dimension of beam specimens

\begin{tabular}{|c|c|c|c|c|c|c|c|c|}
\hline Beam & Mix & $\begin{array}{c}\text { Number of } \\
\text { samples }\end{array}$ & $\begin{array}{c}t \\
\mathrm{~mm}\end{array}$ & $\begin{array}{c}D \\
\mathrm{~mm}\end{array}$ & $\begin{array}{c}L \\
\mathrm{~mm}\end{array}$ & $\begin{array}{c}S \\
\mathrm{~mm}\end{array}$ & $\frac{\mathrm{a}_{\mathrm{o}}}{\mathrm{mm}}$ & $t$ \\
\hline $\mathrm{A} 1$ & $\mathrm{~A} 1$ & 5 & 1 & 100 & 500 & 300 & 25 & .0 \\
\hline A1 & A & 7 & 5 & 133 & 600 & 400 & נת & 3.3 \\
\hline & A 1 & & & 200 & 900 & 600 & 50 & 5.0 \\
\hline & A2 & 5 & 1 & 100 & 500 & 300 & 2 & 4.0 \\
\hline & A2 & & & 133 & 600 & 400 & 33 & 5.3 \\
\hline 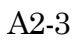 & A & & 8 & 200 & 900 & 600 & 50 & 8.0 \\
\hline & $\mathrm{A} 3$ & 5 & 1 & 100 & 500 & 300 & 25 & 2.5 \\
\hline & $\mathrm{A}$ & 5 & & 200 & 900 & 600 & 50 & 5.0 \\
\hline A3-3 & A3 & 5 & 100 & 100 & 500 & 300 & 25 & 6.25 \\
\hline
\end{tabular}

\section{Three-point Bend (TPB) Testing Set-up}

The TPB test was carried out using a servo-hydraulic closed-loop testing machine with a maximum capacity of $600 \mathrm{kN}$ in the material and concrete laboratory, University of Surrey, UK (Figure 2). A 10 $\mathrm{kN}$ capacity load cell was used to measure the applied load. The loading rate of all the specimens tested was controlled by applying a vertical displacement of $0.01 \mathrm{~mm} / \mathrm{s}$ [26]. The vertical deflection of the beam was measured at the loading point using a calibrated LVDT having a capacity and linearity of $7.5 \mathrm{~mm}$ and $\pm 0.0007 \mathrm{~mm}$, respectively. The crack mouth opening displacement was measured using a clip gauge, Figure 1, with total range of $2 \mathrm{~mm}$ and accuracy of $0.001 \mathrm{~mm}$.

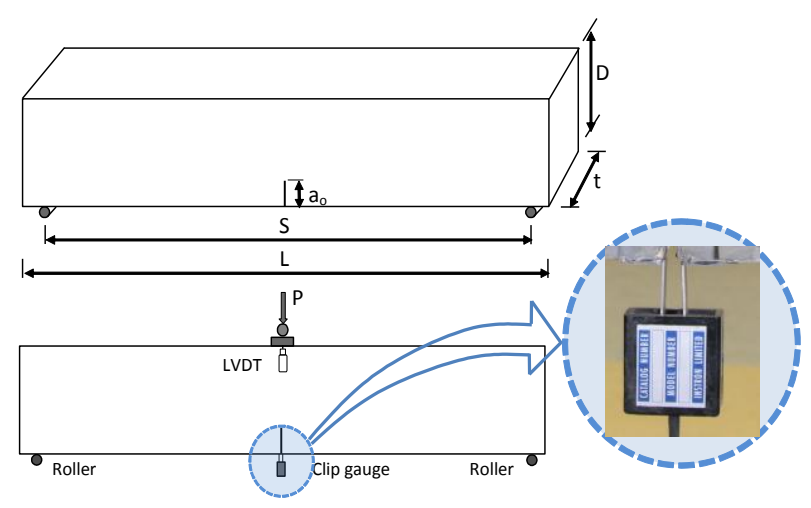

Figure 1. Geometry of Specimen and Test Set Up

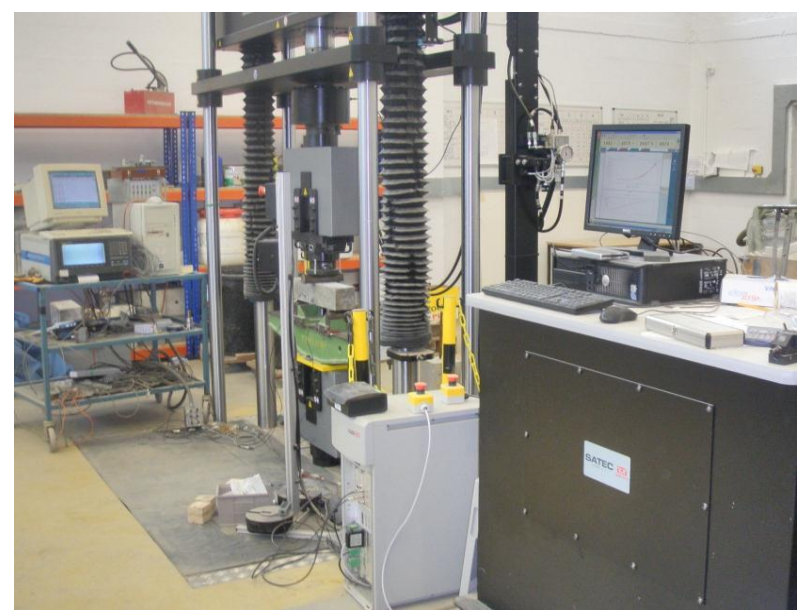

Figure 2. Servo-hydraulic Closed-loop Testing Machine

\section{Results}

The compressive strength $\left(f_{c}\right)$, and the measured fracture characteristics of concrete, i.e. total fracture energy $\left(G_{F}\right)$ and critical stress intensity factor $\left(K_{I C}\right)$ are shown in Table 3 . The fracture characteristics of concrete are discussed in detail in the following subsection. 
Table 3. Mechanical and Fracture Parameters

\begin{tabular}{|c|c|c|c|c|c|c|c|c|c|c|c|c|}
\hline \multirow{2}{*}{ Beam } & \multirow{2}{*}{$\mathrm{w} / \mathrm{b}$} & \multicolumn{2}{|c|}{$f_{c}$} & \multicolumn{3}{|c|}{$G_{F}$ (Deflection) } & \multicolumn{3}{|c|}{$G_{F}\left(\mathrm{CMOD}^{*}\right)$} & \multicolumn{3}{|c|}{$K_{I C}$} \\
\hline & & $\mathrm{MPa}$ & stdev* & $\mathrm{N} / \mathrm{m}$ & stdev & $c_{\mathrm{V}}{ }^{*}$ & $\mathrm{~N} / \mathrm{m}$ & stdev & $c_{V}$ & MPa.mm ${ }^{1 / 2}$ & stdev & $c_{\mathrm{V}}$ \\
\hline $\mathrm{A} 1-1$ & 0.3 & 62 & 5.4 & 234.9 & 36.8 & $15.7 \%$ & 250.3 & 36.9 & $14.7 \%$ & 31.7 & 2.7 & $8.5 \%$ \\
\hline $\mathrm{A} 1-2$ & 0.3 & 62 & 5.4 & 189.4 & 27.7 & $14.6 \%$ & 228.2 & 14.8 & $6.5 \%$ & 31.1 & 2.9 & $9.3 \%$ \\
\hline $\mathrm{A} 1-3$ & 0.3 & 62 & 5.4 & 240.2 & 20.2 & $8.4 \%$ & 270.9 & 21.4 & $7.9 \%$ & 32.9 & 2.6 & $7.9 \%$ \\
\hline A2-1 & 0.3 & 60 & 6.1 & 210.5 & 27.3 & $12.9 \%$ & 220.2 & 33.5 & $15.2 \%$ & 29.8 & 2.3 & $7.7 \%$ \\
\hline A2-2 & 0.3 & 60 & 6.1 & 193.7 & 18.4 & $9.5 \%$ & 234.1 & 17.6 & $7.5 \%$ & 31.4 & 2.7 & $8.6 \%$ \\
\hline $\mathrm{A} 2-3$ & 0.3 & 60 & 6.1 & 238.9 & 17.7 & $7.4 \%$ & 269.6 & 19.7 & $7.3 \%$ & 32.4 & 2.2 & $6.8 \%$ \\
\hline A3-1 & 0.2 & 87 & 2.2 & 165.1 & 28.3 & $17.1 \%$ & 197.6 & 28.5 & $14.4 \%$ & 36.9 & 1.4 & $3.8 \%$ \\
\hline A3-2 & 0.2 & 87 & 2.2 & 208.6 & 12.5 & $6.0 \%$ & 247.5 & 11.4 & $4.6 \%$ & 38.5 & 1.6 & $4.2 \%$ \\
\hline A3-3 & 0.2 & 87 & 2.2 & 206.8 & 8.1 & $3.9 \%$ & 241.2 & 9.6 & $4.0 \%$ & 38.5 & 1.6 & $4.2 \%$ \\
\hline
\end{tabular}

${ }^{*}$ stdev $=$ standard deviation of samples, $\mathrm{c}_{\mathrm{v}}=$ coefficient of variation, $\mathrm{CMOD}=$ crack mouth opening displacement

\section{Fracture Energy, $G_{F}$}

The value of $G_{F}$ of each specimen was calculated from experimental test based on the RILEM TC50FCM recommendation [21], the effect of self-weight of beam was considered. The value of $G_{F}$ was calculated as follows

$G_{F}=\frac{W_{0}+m g \delta_{0}}{\left(D-a_{0}\right) t}$

where $G_{F}$ is the fracture energy, $W_{o}$ is the area under the load-deflection curve, $m$ is the total mass of specimen between supports, $g$ is gravity, $\delta_{o}$ is the end deflection at $\mathrm{P}=0$ when the specimen is totally fail, and $D, a_{o}$ and $t$ are the height of the sample, depth of the notch, and width of the sample, respectively.

\section{Stress Intensity Factor, $K_{I C}$}

$K_{I C}$ as a parameter of fracture toughness of material (indicating the initiation of crack) is a function of applied load, boundary conditions, crack length, and structural geometry [1]. The value of $K_{I C}$ of each sample was carried out by adopting the RILEM TC89-FMT recommendation [27] on the basis of three-bend test method as follows

$K_{I C}=3\left(P_{c}+0.5 W\right) \frac{S\left(\pi a_{c}\right)^{0.5} g\left(a_{c} / D\right)}{2 D^{2} t}$

in which

$g\left(\frac{a_{c}}{D}\right)=\frac{1.99-\left(\frac{a_{c}}{D}\right)\left(1-\frac{a_{c}}{D}\right)\left[2.15-3.93\left(\frac{a_{c}}{D}\right)+2.70\left(\frac{a_{c}}{D}\right)^{2}\right]}{\sqrt{\pi}\left[1+2\left(\frac{a_{c}}{D}\right)\right]\left[1-\left(\frac{a_{c}}{D}\right)\right]^{3 / 2}}$

where $P_{c}$ is the critical maximum load, $\mathrm{W}$ is the selfweight of the beam, $\mathrm{S}$ is span of specimen, $a_{c}$ is critical effective elastic crack length, D is depth of specimen, and $t$ is width of specimen.

\section{Discussion}

Figures 3 to 5 show the response of beam tested on the basis of the normalized stress-deflection curve of concrete for various sizes of specimens. The normalized curve is chosen to show the trend of softening curve [1] of each specimen in order to investigate qualitatively the effect of the ratio of beam width to maximum aggregate $\left(t / d_{\mathrm{a}}\right)$ on the fracture parameters $\left(K_{I C}\right.$ and $\left.G_{F}\right)$. The specimen size of $40 \times 100 \times 500 \mathrm{~mm}$ (A1-1) in which the ratio of beam width to maximum aggregate $\left(t / d_{\mathrm{a}}\right)$ was 2.5 , Table 2, (close to the $t / d$ a ratio suggested by Bazant and $\mathrm{Oh}[22]$ ) was used to investigate the behavior of beam specimens. Although it is a qualitative analysis on the stress/peak stress against deflection curve, it apparently shows that the curve drops sharply after peak stress and the tail of curve vanishes before deflection of $0.4 \mathrm{~mm}$ (Figure 3(a)). Pre-existing flaws such as capillary voids exist in the hardened concrete [28] and these defects initiate cracks [29] when stress intensity subjected by applied stress exceeds the critical stress intensity factors of material. A crack, then, propagates to search weakest link in the concrete. As aggregate is a crack growth arrester in concrete [30], the fracture process of concrete is then dependent on the strength of interfacial zone matrix and the aggregate. When the strength of the aggregate is higher than that of the interfacial zone matrix, the initial crack propagates in the vicinity of the aggregate particles. In this mechanism, the maximum size of aggregate, which controls the $t / d_{\mathrm{a}}$ ratio, then, dictates cracking path and affects the behavior of the beam specimen which is characterized by normalized stress-deflection curve. Since the $t / d$ a ratio is not properly provided by the specimens, the applied stress cannot be appropriately transferred to the particles in the concrete and vice versa. As a consequence, a steep decline curve of normalized stress against deflection is produced as shown on specimen size of $40 \times 100 \times$ $500 \mathrm{~mm}$ in Figure 3(a). However, specimen sizes of $53 \times 133 \times 600 \mathrm{~mm}\left(\mathrm{~A} 1-2, t / d_{\mathrm{a}}\right.$ ratio of 3.3) and $80 \mathrm{x}$ $200 \times 900$ (A1-3, $t / d_{\mathrm{a}}$ ratio of 5 ), demonstrate different softening curves which have longer tails and drop gradually. The change in the shape of the softening curve may influence the measured value of fracture parameters, i.e. $K_{I C}$ and $G_{F}$. As these parameters are representation of fracture behavior of concrete before and after peak stress, the $t / d_{\mathrm{a}}$ ratio of 
the specimen should be considered in the testing (appropriate beam specimens) to measure specific fracture parameters of hardened concrete.

Observing the coefficient of variation $\left(\mathrm{c}_{\mathrm{v}}\right)$ of the measured value of the fracture parameters was intended to evaluate the effect of sample size on the variability of both $K_{I C}$ and $G_{F}$ values. It was computed by dividing the standard deviation, stdev, over the mean value, $\mu$, of samples (stdev/ $\mu$ ). The $c_{v}$ of the measured $K_{I C}$ for sample sizes of $40 \times 100 \times$ 500 (A1-1), $53 \times 133 \times 600$ (A1-2), and $80 \times 200 \times 900$ (A1-3) are $8.5 \%, 9.3 \%$, and $7.9 \%$ respectively. The current experimental results show that the variability of the measured value of $K_{I C}$ is relatively same as increasing $t / d_{\mathrm{a}}$ ratio of the specimens. This indicates that specimen size used in the test gives insignificant effect on the measured value of $K_{I C}$. However, the $c_{\mathrm{v}}$ of the measured value of $G_{F}$ of the concrete shows a different trend compared to the measured value of $K_{I C}$, the $c_{\mathrm{v}}$ of the measured value of $G_{F}$ for specimen sizes of $40 \times 100 \times 500$ (A1-1), $53 \times 133 \times 600$ (A1-2), and $80 \times 200 \times 900$ (A1-3) are $15.7 \%, 14.6 \%$ and $8.4 \%$ on the basis of load - deflection curve, and 14.7\%, $6.5 \%$, and $7.9 \%$ on the basis of load - CMOD curve, respectively. The $c_{\mathrm{v}}$ of specimens tested tends to decrease as the $t / d_{\mathrm{a}}$ ratio of the specimen increases. As fracture characteristic of concrete after peak stress is dependent on the propagation of crack path, the $t / d_{\mathrm{a}}$ ratio of the specimen, which affects the distribution of the applied stress surrounding the aggregate particles, will play an important role in determining of the fracture energy of the concrete.

Whilst there has been an indication that specimen size affects the measured value of $G_{F}$ for the specimens made of mix A1 (using maximum aggregate size of $16 \mathrm{~mm}$ ), the mix A2 which manufactured using maximum aggregate of $10 \mathrm{~mm}$ was engaged in order to compare with the current experimental results discussed in the previous paragraph. Figure 4 shows the typical normalized stress against deflection of beam specimens made of mix A2. For specimens of $40 \times 100 \times 500 \mathrm{~mm}\left(\mathrm{~A} 2-1, t / d_{\mathrm{a}}\right.$ ratio of 4) show to have tendency of producing longer tail curves (Figure $4 \mathrm{a}$ ), and also variation of the curves is less than that of specimens manufactured with $t / d_{\text {a }}$ ratio of 2.5 (Figure 3a). Table 3 shows that variation of the measured value of $K_{I C}$ for specimen sizes of 40 x $100 \times 500(\mathrm{~A} 2-1), 53 \times 133 \times 600(\mathrm{~A} 2-2)$ and $80 \mathrm{x}$ $200 \times 900 \mathrm{~mm}(\mathrm{~A} 2-3)$ are $7.7 \%, 8.6 \%$ and $6.8 \%$ respectively. These variations are thought to be relatively same in which those are mostly less than that of specimen manufactured with $t / d$ a ratio of 2.5 (as discussed in the previous paragraph). On the other hand, the measured value of $G_{F}$ of the concrete for specimens of $40 \times 100 \times 500$ (A2-1), 53 × $133 \times 600$ (A2-2) and $80 \times 200 \times 900 \mathrm{~mm}$ (A2-3) provide variation of $12.9 \%, 9.5 \%$ and $7.4 \%$ respectively. These results demonstrate an indication of the influence of $t / d_{\mathrm{a}}$ ratio on calculating the $G_{F}$ of the concrete is significant; the variation of the value of $G_{F}$ reduces as $t / d_{\mathrm{a}}$ ratio of specimen increases.
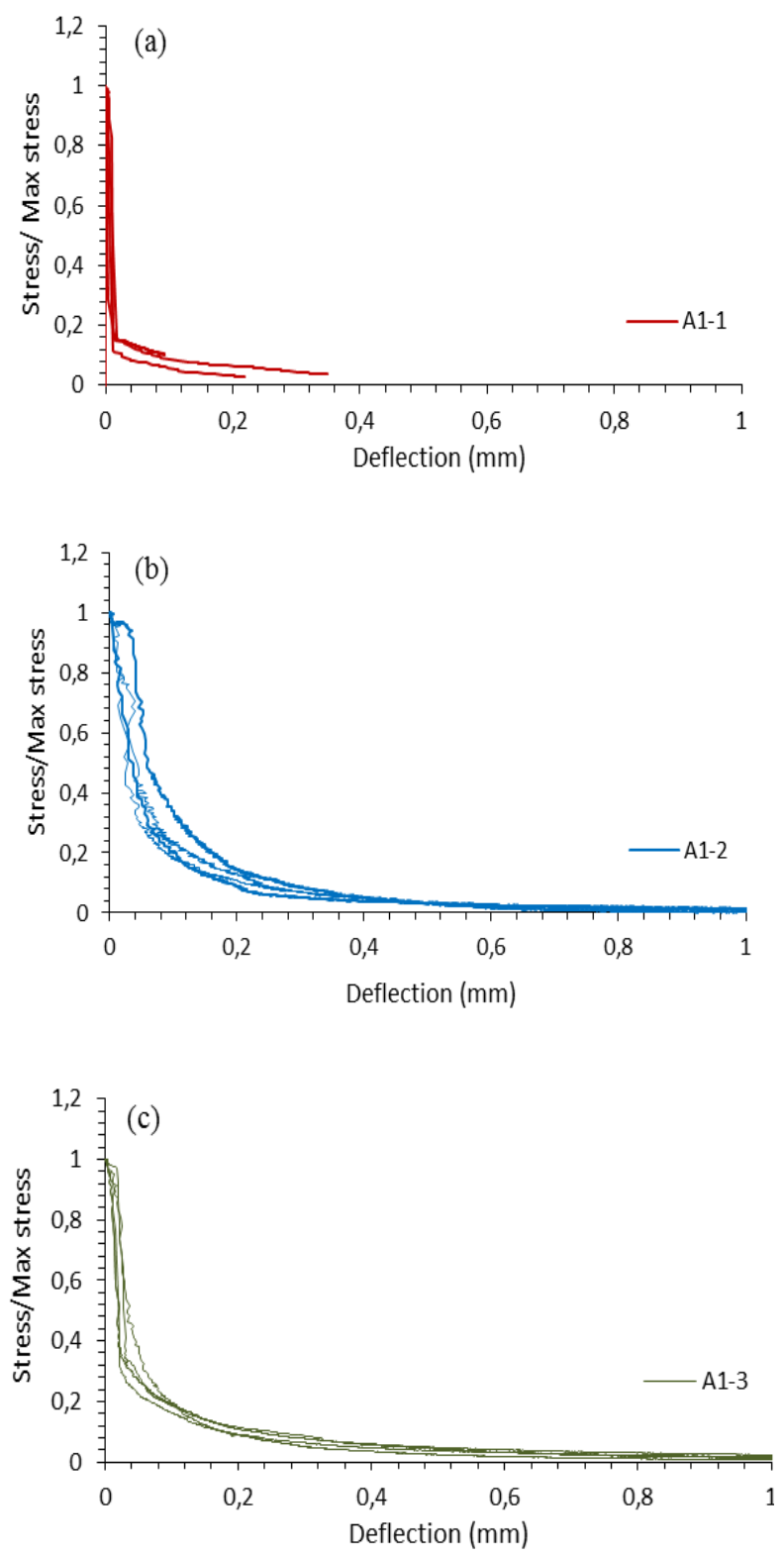

Figure 3. Typical Normalized Stress-deflection of Specimens Made of mix A1 for Size of (a) 40 x $100 \times 500$ mm, (b) $53 \times 133 \times 600 \mathrm{~mm}$, and (c) $80 \times 200 \times 900 \mathrm{~mm}$.

As concrete is a composite material in which the behavior of material will be dependent on the materials used, both low strength and high strength hardened concrete should be examined to have appropriate results. Mixes A1 and A2 which were represented of concrete with high w/b ratio (or low strength hardened concrete) and then, mix A3 was employed to analyze the effect of specimen size $\left(t / d_{\mathrm{a}}\right.$ ratio) on the measured value of both $K_{I C}$ and $G_{F}$ for concrete with low w/b ratio (or high strength hardened concrete). The normalized stress-deflection curves of concrete for specimen sizes of $40 \times 100 \times$ $500 \mathrm{~mm}\left(\mathrm{~A} 3-1, t / d_{\mathrm{a}}\right.$ ratio of 2.5), $80 \times 200 \times 900 \mathrm{~mm}$ 
$\left(\mathrm{A} 3-2, t / d_{\mathrm{a}}\right.$ ratio of 5$)$, and $100 \times 100 \times 500 \mathrm{~mm}(\mathrm{~A} 3-3$, $t / d_{\mathrm{a}}$ ratio of 6.25) are shown in Figure 5. In high strength hardened concrete manufactured with maximum aggregate size of $16 \mathrm{~mm}$ shows that the variation of curves decreases with increasing $t / d_{\mathrm{a}}$ ratio of specimen. Variation of the measured value of $K_{I C}$, Table 3, shows a similar result for all specimens and nevertheless variation of the measured value of $G_{F}$ decreases as $t / d_{\mathrm{a}}$ ratio of specimen increases. Taken together the results of both low and high strength concrete that $t / d_{\mathrm{a}}$ ratio provided by specimen was found to influence on the measured $G_{F}$ of concrete and was essentially independent to measure $K_{I C}$
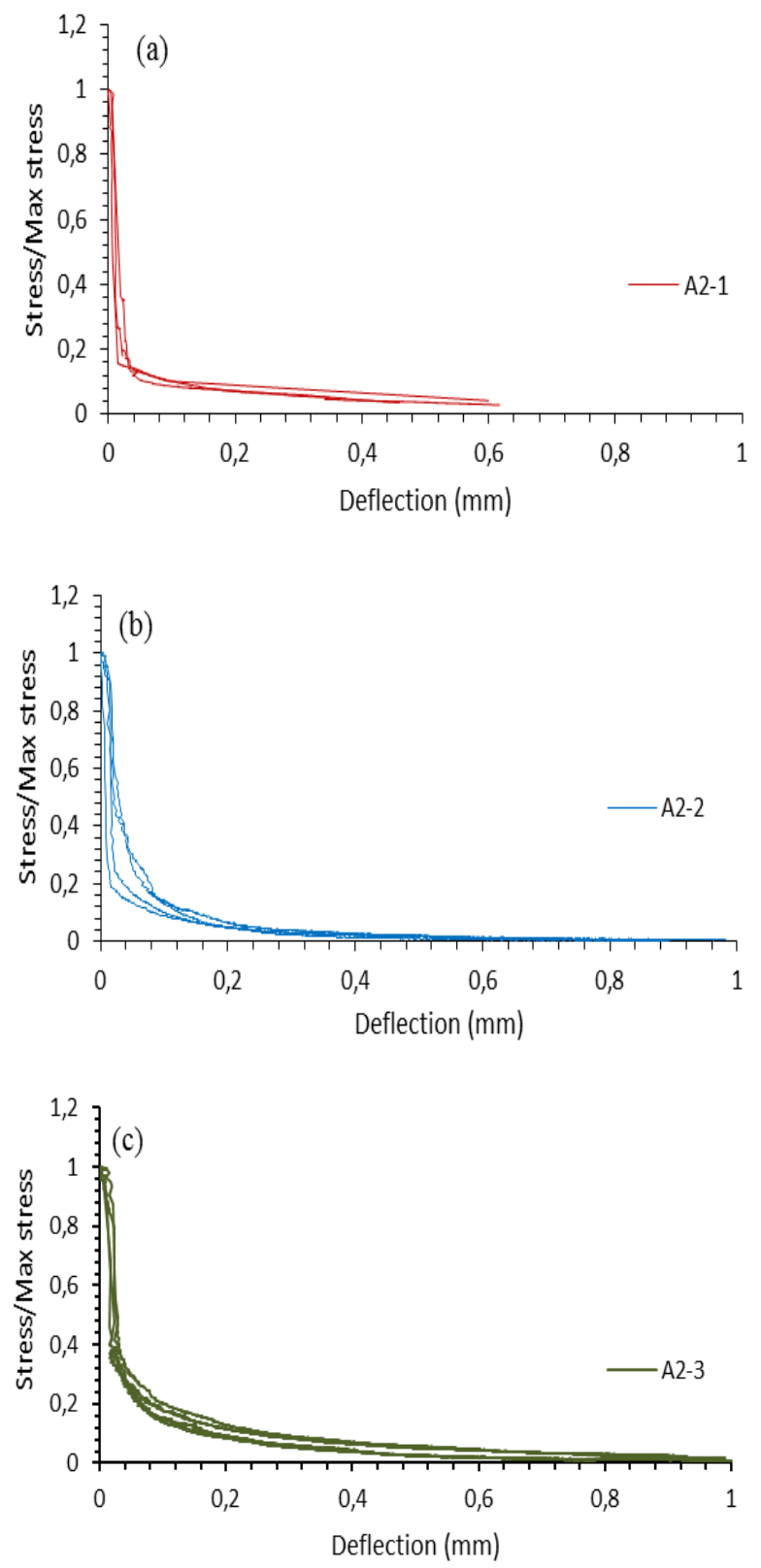

Figure 4. Typical Normalized Stress-deflection of Specimens Made of Mix A2 for Sizes of (a) 40 x 100 x 500 mm, (b) $53 \times 133 \times 600 \mathrm{~mm}$, and (c) $80 \times 200 \times 900 \mathrm{~mm}$.
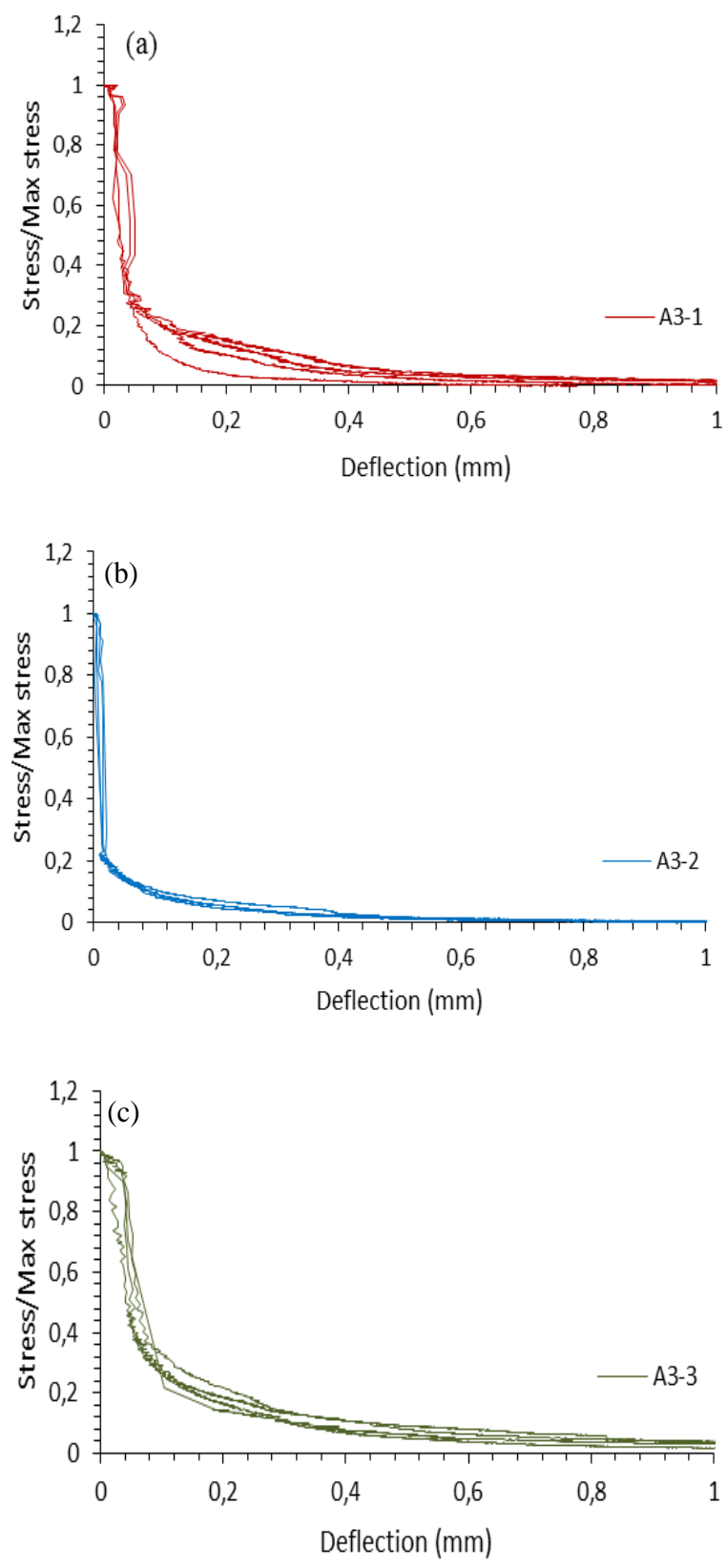

Figure 5. Typical Normalized Stress-deflection of Specimens Made of Mix A3 for Sizes of (a) 40 x 100 x 500 mm, (b) $80 \times 200 \times 900 \mathrm{~mm}$, and (c) $100 \times 100 \times 500 \mathrm{~mm}$

\section{Conclusion}

Based on the investigation on the measured stress intensity factor and fracture energy of concrete through three different specimen sizes by the means of the coefficient of variation, some conclusions can be drawn as follows:

1. The specimen sizes tested in this investigation in deal with the $t / d_{\mathrm{a}}$ ratio of specimen does not influence significantly on variation of the measured $K_{I C}$. This effect has been taken into account by the geometry factor of specimens tested which is proposed by RILEM TC89-FMT recommendation. 
2. Measuring the specific $G_{F}$ of concrete using Three Point Bend test method should consider $t / d_{\mathrm{a}}$ ratio of specimens as $\mathrm{c}_{\mathrm{v}}$ of the measured $G_{F}$ reduces when increasing $t / d_{\mathrm{a}}$ ratio of the specimen.

3. Based on the experimental investigation results, specimen with $t / d_{\mathrm{a}}$ ratio of 4 is a minimum size recommended to use in determining the specific $G_{F}$ of concrete using Three Point Bend test method.

\section{References}

1. Shah, S.P., Swartz, S.E., and Ouyang, C., Fracture Mechanics of Concrete, John Willey and sons Inc., Canada, 1995.

2. Zhu, X.K. and Joyce, J.A., Review of Fracture Toughness (G, K, J, CTOD, CTOA) Testing and Standardization, Engineering Fracture Mechanics, 2012, 79, pp. 36-42.

3. Rocco, C.G. and Elices, M., Effect of Aggregate Shape on the Mechanical Properties of a Simple Concrete. Engineering Fracture Mechanics, 2009, 76, pp. 286-298.

4. Beygi, M.H.A., Kazemi, M.T, Nikbin, I.M., Amiri, J.V., Rabbanifar, S., and Rahmani, E., The Influence of Coarse Aggregate Size and Volume on the Fracture Behavior and Brittleness of Self-Compacting, Cement and Concrete Research, 2014, 66, pp. 75-90.

5. Barr, B.I.G., Hasso, E.B.D., and Weiss, V.J., Effect of Specimen and Aggregate Sizes upon the Fracture Characteristics of Concrete, The International Journal of Cement Composites and Lightweight Concrete, 1986, 8(2), pp. 109119.

6. Wolinski, S., Hordijk, D.A., Reinhardt, H.W., and Cornelissen, H.A.W., Influence of Aggregate Size on Fracture Mechanics Parameters of Concrete, International Journal of Cement Composites and Lightweight Concrete, 1987, 9, pp. 95103.

7. Mihashi, N. and Nomura, N., Influence of Aggregate Size on Fracture Process Zone of Concrete Detected with Three Dimensional Acoustic Emission Technique, Cement and Concrete Research, 1991, 21, pp. 737-744.

8. Guinea, G.V, El-Sayed, K., Rocco, C.G., Elices, M., and Planas, J., The Effect of the Bond between the Matrix and the Aggregates on the Cracking Mechanism and Fracture Parameters of Concrete, Cement and Concrete Research, 2002, 32(12), pp. 1961-1970.

9. Chen, B. and Liu, J., Effect of Aggregate on the Fracture Behavior of High Strength Concrete, Construction and Building Materials, 2004, 18 (8), pp. 585-590.

10. Zhang, B., Cullen, M., and Kilpatrick, T., Fracture Toughness of High Performance Concrete Subjected to Elevated Temperatures: The
Effects of Heating Temperatures and Testing Conditions (Hot and Cold), The 2013 World Congress on Advance in Structural Engineering and Mechanics (ASEM 13), Korea, 2013.

11. Das, S., Aguayo, M., Sant, G., Mobasher, B., and Neithalath, N., Fracture Process Zone and Tensile Behavior of Blended Binders Containing Limestone Powder, Cement and Concrete Research, 2015, 73, pp. 51-62.

12. Nallathambi, P., Karihaloo, B., and Heaton, B. S., Various Size Effects in Fracture of Concrete, Cement and Concrete Research, 1980, 10, pp. 91101.

13. Hillerborg, A.A., Result of Three Comparative Test Series for Determining the Fracture Energy $\mathrm{G}_{\mathrm{F}}$ of Concrete, RILEM Materiaux et Constructions, 1985, 18(107), pp. 33-39.

14. Wolinski, S., Hordijk, D. A., Reinhardt, H. W., and Cornelissen, H. A. W., Influence of Aggregate Size on Fracture Mechanics Parameters of Concrete, International Journal of Cement Composites and Lightweight Concrete, 1987, 9, pp. 95-103.

15. Zhou, F. P., Barr, B. I. G., and Lydon, Fracture Properties of High Strength Concrete with Varying Silica Fume Content and Aggregates, Cement and Concrete Research, 1995, 25(3), pp. 543-552.

16. Wu, K. R., Chen, B., Yao, W., and Zhang, D., Effect of Coarse Aggregate Type on Mechanical Properties of High-Performance Concrete, Cement and Concrete Research, 2001, 31(10), pp. 1421-1425.

17. Xiao, J., Schneider, H., Dönnecke, C., and König, G., Wedge Splitting Test on Fracture Behaviour of Ultra-High Strength Concrete, Construction and Building Materials, 2004, 18(6), pp. 359-365.

18. Comite Euro-International Du Beton, CEB-FIP Model Code 1990, Thomas Telford, London, UK, 1993.

19. Bazant, Z.P. and Becq-Giraudon, E., Statistical Prediction of Fracture Parameters of Concrete and Implications for Choice of Testing Standard, Cement and Concrete Research, 32(4), 2002, pp. 529-556.

20. Comite Euro-International Du Beton, CEB-FIP Model Code 2010 (first draft), Bulletin D'Information 2123/214, Laussen, Switzerland, 2010.

21. RILEM Committee FMC 50, Determination of the Fracture Energy of Mortar and Concrete by Means of Three-Point Bend Tests on Notched Beams, Material Structures, 1985, 18(106), pp. 285-290.

22. Bazant, Z.P. and Oh, B.H., Crack Band Theory for Fracture of Concrete, RILEM Materiaux et Constructions, 1983, 16 (93), pp. 155-157. 
23. BS EN450-1, Fly Ash for Concrete: Finesses Category S, European Committee for Standardization, Brussels, 2005

24. BS EN 12363-1, Silica Fume for Concrete, European Committee for Standardization, Brussels, 2005

25. BS EN 12390-3, Testing Hardened Concrete, European Committee for Standardization, Brussels, 2001

26. Zhang, X.X., Ruiz, G., Yu, R.C., and Tarifa, M., Fracture Behaviour of High Strength Concrete at Wide Range of Loading Rates, International Journal of Impact Engineering, 2009, 36(10-11), pp. 1204-1209.
27. RILEM TC89-FMT Recommendation, Fracture Mechanic of Concrete Test Method, Material and Structures, 1990, 23, pp. 247-252.

28. Mehta, P.K., Concrete Structure, Properties and Materials, Prentice-Hall Inc., New Jersey, USA, 1986.

29. Utomo, P. and Nikraz, H. R., Evaluation of Finite Element Mesh Arrangements and Stress Intensity Factor Calculation Methods for Opening Mode Fracture of Cracked-Cemented Materials, Civil Engineering Dimension, 2007, 9(1), pp. 25-32.

30. Giaccio G. and Zerbino R., Failure Mechanism of Concrete: Combined Effect of Coarse Aggregate and Strength Level, Advance Cement Based Materials, 1998, 7(2), pp. 41-48. 